\title{
Kielitutkinto porttina Suomeen ja astinkivenä suomen kieleen
}

\author{
MINNA MARTIKAINEN \\ Jyväskylän yliopisto
}

Tiivistelmä. Artikkelissa tarkastellaan inkeriläisten paluumuuttajien käsityksiä kielitutkinnosta, joka heidän oli suoritettava saadakseen oleskeluluvan Suomeen niin sanotulla inkeriläisstatuksella. Kielitutkinto oli käytössä vuosina 2003-2016. Tarkastelun kohteena ovat myös tämän kielitutkinnon vaikutukset kielenopiskeluun. Aineistona ovat paluumuuttovalmennukseen osallistuneiden, tutkintoon valmistautuneiden henkilöiden ( $\mathrm{n}=$ 97) vastaukset kyselyyn, jonka he tekivät ennen kielitutkinnon suorittamista. Aineistoa tarkastellaan sisällönanalyysin keinoin. Aineiston perusteella kielenoppijat tiesivät tutkinnon rakenteesta ja sen suorittamisesta tietokoneella. Suorittajat olivat hyvin tietoisia myös siitä, että tutkinnon hyväksytty suorittaminen on edellytys Suomeen muutolle. Huomiota herättävää tässä aineistossa oli tutkinnon suorittajien myönteinen suhtautuminen kielitutkintoon ja kielen opiskeluun: tutkinnon lähetessä kielen opiskelusta oli tullut kiinnostavampaa ja mieluisampaa kuin ennen. Se, mitä tutkinnosta ajatellaan, voi vaikuttaa voimakkaasti siihen, kuinka tutkintoon valmistaudutaan ja miten tutkinnossa onnistutaan. Tämän aineiston perusteella inkeriläisopiskelijoilla oli hyvät edellytykset onnistua tutkinnossaan.

Avainsanat: inkeriläiset; kielitaidon arviointi; kielitutkinnot; suomen kieli; vaikutus 


\section{Inkeriläisten paluumuuttajien kielitutkinto osana paluumuuttoprosessia}

Inkeriläisten muutto entisen Neuvostoliiton alueilta Suomeen käynnistyi presidentti Mauno Koiviston vuonna 1990 antaman lausunnon jälkeen, kun hän totesi, että inkeriläisiä voidaan pitää paluumuuttajina (Yleisradio 1990). Lausunnon jälkeen alettiin tehdä virkamiespäätöksiä, joiden pohjalta varsinainen paluumuutto käynnistyi. Paluumuuton säädöksiä muutettiin 1.10.2003, jolloin voimaan tuli ulkomaalaislain 18 §:n muutos (N:o 218/2003). Henkilön, joka tämän pykälän perusteella haki oleskelulupaa Suomeen, oli osoitettava riittävä suomen kielen taito. Inkeriläisten paluumuuttajien kielitutkinto Ipaki kehitettiin vuonna 2003 todentamaan inkerinsuomalaisten paluumuuttajien suomen kielen taitoa. Tutkinto digitalisoitiin vuonna 2005 ja siitä lähtien tutkinnosta on käytetty nimitystä Dipaki. (Kärkkäinen \& Lankinen 2008; Martikainen 2016: 46)

Dipaki oli kolmentoista vuoden ajan, vuosina 2003-2016, osa paluumuuttoprosessia. Suomeen muuttoa suunnitelleet inkeriläiset osallistuivat paluumuuttovalmennukseen ja suorittivat sen jälkeen Eurooppalaisen viitekehyksen A2-tasolla olevan Dipaki-kielitutkinnon, joka oli räätälöity juuri tätä kielitaidon arviointitilannetta varten (Työministeriö 2003a). Suomen Maahanmuuttovirasto järjesti tutkinnon ja teki oleskelulupapäätöksiä osin tämän kielitutkintotodistuksen perusteella. Tutkinto on opettajien mukaan vaikuttanut voimakkaasti valmennuskurssin sisältöön ja tehtävätyyppien suunnitteluun (Martikainen tulossa). Aiemmat tutkimukset ovat osoittaneet, että tutkinnolla voi olla vaikutuksia myös sen suorittajien opiskeluasenteeseen, opiskelukäytänteisiin ja motivaatioon (Loumbourdi 2014: 139-144). Nämä tekijät voivat vaikuttaa tutkinnossa suoriutumiseen ja siten tutkinnon validiteettiin (Messick 1996; Stricker \& Attali 2010), joka on yksi keskeinen tutkinnon laatutekijä (esim. Bachman \& Palmer 1996).

Dipaki-kielitutkintoon osallistui aikavälillä 1.12.2003-30.6.2016 yhteensä 5476 henkilöä. Tutkinnon läpäisyprosentti on ollut keskimäärin 
80,70. (Maahanmuuttovirasto 2016) Dipaki-tutkinnon läpäisemisellä tai läpäisemättä jäämisellä saattoi olla merkittäviä seurauksia tutkinnon suorittajan elämälle, sillä tutkintoa ei voinut uusia. Kyseessä oli siis high stakes -tutkinto. Jos epäonnistui tutkinnossa eikä saanut hyväksyttyä tulosta, kielitaidon saattoi kuitenkin todistaa Yleisen kielitutkinnon avulla. (Kärkkäinen \& Lankinen 2008; Maahanmuuttovirasto 2015a) Tämä tutkinnon kertaluontoisuus on varsin poikkeuksellista, useat kielitutkinnot kun voi yleensä vapaasti uusia (esim. englannin kielen tutkinnot TOEFL iBT Test ja IELTS). Vastaava tapaus löytyy kuitenkin Saksasta: siellä Venäjällä asuvan ja Saksaan muuttavan väestön kohdalla vuonna 1996 käyttöön tulleen kielikokeen saa suorittaa vain kerran. Sen tarkoituksena on ollut selvittää, onko saksalainen kulttuuriperintö säilynyt. (Struck-Soboleva 2006; Työministeriö 1998)

Dipaki-tutkintoa suoritettiin Venäjällä Pietarissa, Petroskoissa ja Moskovassa sekä aiemmin, vuoteen 2008 myös Virossa Tartossa. Myös Suomessa tutkintotilaisuuksia järjestettiin jonkin verran. Suomessa tutkinnon suorittajia oli yhteensä 587 henkilöä kaikkiaan 5476:sta (Maahanmuuttovirasto 2015b; Maahanmuuttovirasto 2016). Tutkintoon menoa muualla kuin Suomessa edelsi paluumuuttovalmennus, jonka keskeisenä sisältönä oli suomen kieli. Opettajina toimivat paikalliset opettajat. Valmennusta järjestettiin lukuvuoden kestävänä iltaopetuksena, jota oli pääsääntöisesti kahtena iltana viikossa neljä tuntia kerrallaan (Mielonen 2014; 2015). Valmennuskurssien koordinoijana ja opettajien ohjaajana toimi suomalainen oppilaitos, Etelä-Kymenlaakson ammattiopisto Ekami. Kielitutkintoon liittyvän ulkomaalaislain toimeenpanoa ja toteuttamista varten perustettiin työryhmä, jonka tehtävinä olivat muun muassa kielitutkinnon kehittäminen ja toimeenpano sekä kielitutkintoon liittyvän koulutuksen koordinointi (Työministeriö 2003).

Dipakin vaikutuksia on aiemmin tutkittu kielitutkintotyöryhmän asiantuntijajäsenten ja valmennuskurssin opettajien näkökulmasta (Martikainen tulossa). Tämän tutkimuksen valokeilassa ovat henkilöt, jotka ovat valmistautumassa kielitutkintoon. Tavoitteena on selvittää, 
millaisia käsityksiä heillä on tutkinnosta ja mitä vaikutuksia näillä käsityksillä on kielenopiskeluun. Analyysin tulosten perusteella pohdin myös sitä, onko kielitutkinnolla ollut sellaisia vaikutuksia, joita sille vuonna 2003 asetettiin. Tiivistetysti tutkimuskysymykset ovat seuraavat: 1) Millaisia käsityksiä tutkinnon suorittajilla on Dipaki-tutkinnosta? 2) Miten opiskelijat kokevat tutkinnon vaikuttaneen kielen opiskeluunsa? 3) Onko kielitutkinnolla saavutettu sille asetettuja kielen oppimiseen liittyviä tavoitteita? Tutkimustulosten valossa tarkastellaan myös laajempaa kysymystä siitä, voiko kielitutkinto yleensä olla oikea tapa suunnata kielenopetusta. Tutkintojen vaikutukset kun voivat olla niitä, joita niillä tavoitellaan, mutta vaikutukset voivat olla myös yllättäviä ja jopa ei-toivottuja. Huhta ja Hildén muistuttavat, kuinka vaikea on ennustaa kaikkia tutkinnon vaikutuksia. Vaikka esimerkiksi Yleisiä kielitutkintoja (YKIä) luotaessa ajatuksena oli tarjota vaihtoehto kansainvälisille kielitutkinnoille, tutkintoa käytetään nykyään kielitaidon osoittamiseen suomen kansalaisuutta hakiessa. (Huhta \& Hildén 2016: 22) Tätä tuskin tutkinnon kehittäjät aikanaan osasivat ennakoida.

Kielitutkinnon suorittaneiden osuus on vaihdellut alkuvaiheen 68 prosentin ja vuoden 2013 tuloksen 91,3 prosentin välillä (taulukko 1).

TAULUкко 1. Tutkinnon hyväksyttyjen suoritusten lukumäärän kehitys vuosina 2003-2016 (Maahanmuuttovirasto 2015b; 2016)

\begin{tabular}{|l|c|c|c|}
\hline Vuosi & Osallistujamäärä & Hyväksyttyjä & Prosentti \\
\hline 2003 & 50 & 34 & $68,0 \%$ \\
\hline 2004 & 306 & 211 & $68,9 \%$ \\
\hline 2005 & 328 & 251 & $76,5 \%$ \\
\hline 2006 & 491 & 391 & $79,6 \%$ \\
\hline 2007 & 433 & 356 & $82,2 \%$ \\
\hline 2008 & 428 & 320 & $74,8 \%$ \\
\hline 2009 & 405 & 318 & $78,5 \%$ \\
\hline 2010 & 552 & 436 & $78,9 \%$ \\
\hline 2011 & 703 & 565 & $80,4 \%$ \\
\hline
\end{tabular}




\begin{tabular}{|l|c|c|c|}
\hline Vuosi & Osallistujamäärä & Hyväksyttyjä & Prosentti \\
\hline 2012 & 694 & 588 & $84,7 \%$ \\
\hline 2013 & 391 & 357 & $91,3 \%$ \\
\hline 2014 & 254 & 220 & $86,6 \%$ \\
\hline 2015 & 191 & 173 & $90,6 \%$ \\
\hline 2016 & 251 & 197 & $78,5 \%$ \\
\hline Yhteensä & 5476 & 4419 & \\
\hline
\end{tabular}

Hyväksyttyjen arvosanojen keskiarvo vuosina 2003-2016 oli 80,7 prosenttia suoritetuista tutkinnoista. Viimeisinä tutkintovuosina, 20132015, läpäisyprosentit ovat kaikkein suurimmillaan, 87 ja 91 prosentin välillä. Viimeisen tutkintovuoden 2016 notkahdusta voi selittää se, että tuolloin myös ne halusivat käyttää mahdollisuuden yrittää kielitutkinnon suorittamista, jotka eivät aiemmin kielitaitonsa puutteiden vuoksi olleet tutkintoon osallistuneet. Läpäisyprosentin kasvu voi kertoa myös siitä, että tutkintoon hakeutumisvaiheessa, siis myös paluumuuttovalmennuksen yhteydessä, on osattu kertoa tutkinnon vaatimustasosta, jolloin tutkintoon on tullut niitä henkilöitä, joiden kielitaitoa se vastaa.

\section{Oppijoiden käsitykset kielitutkinnoista ja tutkintojen vaikutukset oppimiseen}

Kielenoppijoiden käsitykset kielestä ja sen oppimisesta voivat vaikuttaa oppimiseen, oppimistuloksiin yleensä ja myös kielitutkinnossa onnistumiseen. Vaikutus voi olla oppimista edistävää tai sitä haittaavaa (Kalaja 2015: 10). Monissa kielitutkintojen suorittajia koskevissa tutkimuksissa tarkasteltavana ovat olleet oppijoiden asenteet (engl. attitudes) (esim. Wall 2000; Wall \& Horák 2006; Strickel \& Attali 2010).

Käsitykset ovat olleet tutkimuksen kohteena jo 1970-luvulta lähtien, kun on luotu kuvaa hyvästä kielenoppijasta (Rubin 1975; Griffiths 2008; Kalaja ym. 2015). Aiemmin käsityksiä pidettiin oppijoiden mielipiteinä (engl. opinions), luonteeltaan kognitiivisina ja melko pysyvinä (Wenden 1991: 34-41). Tässä tutkimuksessa käytän käsitys-termiä laajasti 
tarkoittamaan kielenoppijan ajatuksia, tulkintaa todellisuudesta tai tapaa hahmottaa maailmaa ja sen ilmiöitä (esim. Kalaja 2015). Käsitykset syntyvät vuorovaikutuksessa muiden ihmisten kanssa, kun tulkitaan asioita ja ilmiöitä, annetaan niille merkityksiä ja tehdään asioita, esimerkiksi opiskellaan kieltä yhdessä muiden kanssa. Näin muiden ihmisten käsitykset vaikuttavat omien käsitysten muotoutumiseen. Käsitykset eivät ole sinällään oikeita tai vääriä, ja ne voivat vaihdella tilanteesta toiseen. (Kalaja ym. 2015: 10)

Dipaki-kielitutkinnon perusteiden mukaan tutkinnossa testataan viestinnällisen kielitaidon tasoa (Työministeriö 2003). Kun tutkintoa aikanaan luotiin, sen toivottiin tehostavan paluumuuttovalmennusta, kehittävän viestinnällistä kielitaitoa erityisesti puhetaidon osalta ja todentavan kielitaitoa luotettavalla tavalla (Martikainen tulossa). Yleisiin kielitutkintoihin liittyi samansuuntaisia tavoitteita 1990-luvun alkupuolella, kun niitä luotiin: aikuisten kieltenopiskelun edistäminen (Huhta \& Hildén 2016: 16).

Kielitutkintojen vaikutuksia koskevissa tutkimuksissa erotetaan merkitykset, joita ilmaistaan termeillä impact ja washback. Impact on mikä tahansa vaikutus, joka tutkinnolla on yksilöihin tai käytäntöihin luokassa, koulussa, koulutusjärjestelmässä tai yhteiskunnassa. Washback-termillä tarkoitetaan tutkinnon vaikutusta opetukseen ja oppimiseen. (Wall 1997: 291; Cheng 2008: 349) Messick (1996: 242) määrittelee washback-vaikutuksen niin, että opettajat ja opiskelijat tekevät sellaista, mitä eivät tekisi muuten, ilman tutkinnon olemassaoloa. Tämän tutkimuksen keskiössä ovat tutkinnon vaikutukset oppimiseen, joten kyse on washback-tutkimuksesta. Tutkimus ei kuitenkaan rajaudu luokkahuonevaikutuksiin, sillä tarkastelen myös muita mahdollisia tutkinnon aiheuttamia vaikutuksia kielenoppijoihin, ja vaikutukset voivat koskea myös itsenäistä opiskelua kotona tai muitakin seikkoja.

Tutkimuksen teoreettisena viitekehyksenä on Henrichsenin (1989) malli opetuksen innovaation käyttöönotosta (myös esim. Wall \& Horák 2006; 2008) sekä Messickin (1996: 243-247) ajatus siitä, että tutkinnon vaikutukset ovat osa sen validiteettia. Tarkastelen sitä, onko tutkinnon 
(oletetuilla) ominaisuuksilla ja oppijoiden toiminnalla tai valinnoilla yhteneviä piirteitä (Messick 1996: 247). Opetuksen innovaatio on tässä kielitutkinto, johon etsin viitteitä tutkimusaineistosta. Näiden viitteiden avulla on mahdollista osoittaa, onko tutkinnolla ollut washbackvaikutusta. Tarkastelun kohteena ovat kielelliset ilmiöt: mitä tutkinnon suorittajat ovat vastanneet kysymyksiin. Tämän osallistujajoukon käsityksiä tutkinnosta ei ole aiemmin tutkittu lainkaan, joten vertailukohtaa on haettava kansainvälisten kielitutkintojen suorittajia koskevista tutkimuksista (mm. Stricker \& Attali 2010; Loumbourdi 2014).

Teen analyysia aineistolähtöisesti. Keskityn aineistossa kielitutkintoon ja sen vaikutuksiin, mutta otan tarkasteluun aineistoa mahdollisimman laajasti: millaisia käsityksiä, ajatuksia ja tulkintoja osallistujilla on kyseessä olevasta kielitutkinnosta. Tarkastelen aineistoa sisällönanalyysin keinoin eritellen, yhtäläisyyksiä ja eroja etsien (Tuomi \& Sarajärvi 2002: 105). Tekstiä lähestytään sellaisenaan, ei niiden "takana" olevia asenteita tai kognitiivisia prosesseja (Potter \& Wetherell 1987: 60).

\section{Tutkimusaineisto ja -menetelmä}

Tutkimukseeni osallistui keväällä 2016 yhteensä 97 henkilöä, jotka olivat tuolloin paluumuuttovalmennuksessa Pietarissa ja Petroskoissa. Paluumuuttovalmennuksessa oli lukuvuonna 2015-2016 yhteensä 148 henkilöä, ja tutkintoon osallistui vuonna 2016 yhteensä 251 henkilöä. Kaikki tutkintoon tulleet eivät siis käyneet paluumuuttovalmennusta, mutta tutkimukseeni tavoitin vain valmennuksessa olleita. Keräsin aineiston kyselylomakkeella huhtikuussa 2016, jolloin tutkintoon oli aikaa noin kolme viikkoa. Tutkinto järjestettiin 11.-12.5.2016. Tutkimukseeni osallistuneista 57 oli naisia, 40 miehiä. Henkilöiden ikäjakauma painottuu aikuisiin, 26-65 ikävuoteen (taulukko 2) kuten aiempinakin vuosina (Maahanmuuttovirasto 2015b; 2016). Myös sukupuolijakauma on säilynyt naisvoittoisena: vuodesta 2003 alkaen $57-65$ prosenttia on ollut naisia, ja vuonna 2016 naisia oli 59 prosenttia. 
TAULUкко 2. Tutkimukseen osallistuneiden ikäjakauma

\begin{tabular}{|l|c|c|}
\hline Ikä & N & Prosentti \\
\hline 15-25 vuotta & 6 & $6,2 \%$ \\
\hline 26-40 vuotta & 37 & $38,1 \%$ \\
\hline $41-65$ vuotta & 51 & $52,6 \%$ \\
\hline yli 66 vuotta & 3 & $3,1 \%$ \\
\hline Yhteensä & 97 & $100 \%$ \\
\hline
\end{tabular}

Kyselytutkimuksen avulla saatava tieto perustuu vastaajan omaan arvioon. Kyselyn etuna on mahdollisuus tavoittaa laaja joukko tutkinnon suorittajia. Olen osallistunut Dipaki-tutkinnon järjestelyihin myös haastattelijana ja kielitaidon arviojana. Lisäksi vierailin paluumuuttovalmennusryhmissä syksyn 2004 aikana ja tapasin ja haastattelin syksyllä 2016 kaikki tuolloin paluumuuttovalmennuksessa toimineet kahdeksan opettajaa. Tätä kautta minulle on muodostunut omiin, väistämättä subjektiivisiin kokemuksiini perustuva käsitys olosuhteista ja ilmapiiristä, jossa tämän kielitutkinnon parissa toimittiin.

Laadin kyselyn kaksikieliseksi, suomeksi ja venäjäksi, jotta vastaajat saattoivat vastata vahvemmalla kielellään ja kertoa käsityksistään niin tarkasti kuin halusivat. Opiskelijat vastasivat kyselyyn paluumuuttovalmennuskurssilla oman opettajansa läsnä ollessa. En itse ollut paikalla, vaan toimitin kyselyn heille paluumuuttovalmennusta koordinoivan opettajan välityksellä. Selvitin mahdollisuutta internetpohjaiseen kyselyyn, mutta koulutuksen koordinaattori arvioi, että paperiversio tavoittaisi kurssin osallistujat paremmin (Mielonen 2015). Huolena luokkatilanteessa vastaamisessa on se, että opettajien ja muiden opiskelijoiden läsnäolo vastaustilanteessa saattaa vaikuttaa vastauksiin. Kyselyn esittelytekstissä kuitenkin korostin, ettei oikeita tai toivottuja vastauksia ole, vaan haluan tietää heidän ajatuksistaan Dipaki-tutkinnosta. Luokkahuoneessa tehdyn kyselyn etuna on se, että kyselylle on varattu tietty aika oppitunnilla, ja sosiaalinen tilanne voi motivoida vastaamaan luotettavammin kuin itsenäisesti tehtävässä internetkyselyssä. Kyselyn tekeminen opettajan läsnä ollessa saattaa hiukan vähentää voimakkaan 
kielteisiä tai myönteisiä vastauksia tai lisätä vastaamista prestiisiarvojen mukaisesti esimerkiksi kotitehtävien tekemiseen käytetystä ajasta tai niiden sisällöstä, koska vastaaja saattaa pyrkiä vastauksissaan opettajaa miellyttäviin vastauksiin. (Ks. Dörnyei 2009: 7-8)

Kyselyä laatiessani käytin pohjana Hawkeyn (2006), Mooren, Stropen ja Mahonyn (2009) ja Loumbourdin (2014) kyselyitä. Tein samansuuntaisia kysymyksiä esimerkiksi opiskelutavoista ja opiskelun muuttumisesta tutkinnon lähestyessä. Valitsin kyselyyni vain oman tutkimukseni kannalta kaikkein keskeisimmät teemat, kotitehtävien tekeminen ja opiskelutekniikat kielen opiskelussa, tutkintoon liittyvä jännitys ja opiskelussa tapahtuneet muutokset kielitutkinnon lähestyessä. Halusin pitää kyselyn erityisen tiiviinä, jotta saamani vastaukset olisivat harkittuja ja kyselyihin liittyvien haasteiden, esimerkiksi vastausten yksioikoisuuden ja pinnallisuuden (Dörnyei 2009: 7-8), vaikutus jäisi mahdollisimman pieneksi. Lomake koostui avokysymyksistä ja monivalintakysymyksistä (liite 1. Kysely). Kyselyyn vastanneet olivat pääsääntöisesti vastanneet kaikkiin kysymyksiin. Avovastausten pituus vaihteli.

Kyselyssä ei suoraan esitetty kysymystä kielitaidon kehittymisestä valmennuskurssin aikana. En halunnut laajentaa kyselyä tarpeettomasti ja arvioin, että näiden vastausten informaatioarvo olisi melko pieni. Yksilön edellytykset arvioida omaa kielitaitoaan voivat vaihdella hyvin paljon, koska ihmiset painottavat esimerkiksi onnistumisessaan hyvin erilaisia asioita (Williams \& Burden 1997: 105). Kyselyihin vastanneet kielenoppijat on yksilöity juoksevalla numerolla 1-97. Numerojärjestys on satunnainen. Vastauksista valtaosa oli joko kokonaan tai osin venäjänkielisiä. Kokonaan suomeksi oli vastannut viisi henkilöä. Suomenkieliset vastaukset on merkitty esimerkeissä S-kirjaimella, esimerkiksi O6S on kuudes opiskelija, ja hän on vastannut suomeksi. Venäjänkieliset vastaukset on käännetty suomeksi.

Analyysivaiheen alussa poimin aineistosta osioita, jotka ilmaisivat tutkimuksen osallistujien käsityksiä kielitutkinnosta. Tietyt teemat toistuivat, joten päädyin ryhmittelemään ne seuraaviin aihealueisiin: tutkintoon valmistautumiseen käytetty aika, kielitutkinnon luonnehdintaa ja 
muutokset kielitutkinnon lähestyessä. Seuraavassa luvussa tarkastelen näitä kategorioita lähemmin.

\section{Suomen kielen opiskelusta on tullut osa elämää}

Aineistoa tarkastellessani nousi esiin niin tutkintoa ja sen aiheuttamia tunteita kuvailevia kuin sen tarkoitusta ja tarpeellisuutta perustelevia käsityksiä. Näitä käsityksiä tarkastelen alaluvussa 4.2. Analysoin myös opiskelijoiden käsityksiä siitä, millä tavalla tutkinnon lähestyminen on vaikuttanut opiskeluun ja heidän elämäänsä yleensä (luku 4.3). Lopuksi arvioin sitä, näkyykö näissä opiskelijoiden mainitsemissa vaikutuksissa sen suuntaisia muutoksia, joita kielitutkinnolla aikanaan tavoiteltiin (luku 4.4). Ensimmäisenä tarkasteltavana ilmiönä on kuitenkin se, kuinka paljon opiskelijat käyttivät aikaa tutkintoon valmistautuessaan.

\subsection{Tutkintoon valmistautumiseen käytetty aika}

Tutkintoon valmistauduttiin sekä paluumuuttovalmennuksessa pääsääntöisesti kahtena iltana viikossa että myös itsenäisesti. Valtaosa käytti opiskeluun aikaa vähintään 3 tuntia viikossa kurssilla opiskelun lisäksi, mutta vain neljäsosa enemmän kuin neljä tuntia (taulukko 3).

TAuluкко 3. Viikoittainen opiskeluaika paluumuuttovalmennuksen lisäksi

\begin{tabular}{|l|c|c|}
\hline Opiskeluaika viikossa & N & Prosentti \\
\hline Vähemmän kuin 1 tunti & 5 & $5,2 \%$ \\
\hline 1-2 tuntia & 30 & $30,9 \%$ \\
\hline $3-4$ tuntia & 36 & $37,1 \%$ \\
\hline Enemmän kuin 4 tuntia & 26 & $26,8 \%$ \\
\hline Yhteensä & 97 & $100 \%$ \\
\hline
\end{tabular}

Yleensä tutkintoihin valmistauduttaessa viikoittainen opiskeluaika vaihtelee voimakkaasti sekä sen mukaan, valmistaudutaanko tutkintoon 
kurssilla vai itsenäisesti esimerkiksi työn ohessa sekä toki myös yksilön omien, itsenäistä opiskelua koskevien valintojen mukaan. Suomessa Yleisten kielitutkintojen suomen kielen tutkinnon perustason (A1-A2-tason) tutkintoon tulevista 69 prosenttia on opiskellut kieltä yhteensä alle vuoden tutkintoon tullessaan. Noin neljäsosa tuli tutkintoon opiskeltuaan suomea 1-3 vuotta. (Neittaanmäki \& Hirvelä 2014: 59) Tällainen keskimääräinen opiskeluaika on samansuuntainen kuin Dipakin yhteydessä, koska suuri osa paluumuuttovalmennukseen osallistujista aloitti suomen kielen opiskelun vuoden mittaisen valmennuksen alkaessa (Mielonen 2015). Inkeriläisten suhde suomen kieleen ja suomalaisuuteen voi toki olla erilainen kuin muilla, kieltä toisena tai vieraana kielenä opiskelevilla. Ainakin osalla inkeriläisistä suomen kieli on edelleen äidinkieli ja suomalaisuus osa identiteettiä (Iskanius 2006: 172; Davydova 2002: 156-159). Kyse ei ole tällöin ainakaan pelkästään vieraan kielen opiskelusta, vaan suomen kielen opiskelu voi saada muita merkityksiä oman perheen ja suvun perinteisiin tutustumisena ja kulttuuriperinnön vaalimisena.

Kansainvälisiin englannin kielen tutkintoihin valmistautumisaika vaihtelee. Loumbourdin (2014) tutkimuksessa kreikkalaiset opiskelijat opiskelivat kielitutkinnon alla keskimäärin 5-8 tuntia oppituntien lisäksi, moni jopa 9-12 tuntia. Kreikkalaistutkimuksessa selvisi, että itsenäiseen opiskeluun käytetty aika oli kasvanut kielitutkinnon lähestyessä. Tutkija arvioi, että tätä voisi pitää osoituksena washback-ilmiöstä. (Loumbourdi 2014: 79-80) Myös tässä tutkimuksessa useat opiskelijat mainitsevat opiskelevansa aiempaa enemmän (esimerkit 1 ja 2).

(1) Kertaan enemmän joka päivä. (O48)

(2) Opiskelen yhä enemmän ja enemmän. (O89)

Sitä, millaista tuo opiskelu oli, käsittelen alaluvussa 4.3, kun tarkastelen opiskelijoiden käsityksiä siitä, miten tutkinto vaikutti opiskeluun. 


\subsection{Tärkeä, vaikea tutkinto}

Tutkimusaineistossa tutkintoon tulijat kuvailivat kielitutkintoa yleensä tutkinnon rakenteen, sisällön, tehtävätyyppien ja tutkintojärjestelyjen kautta: tutkinto koostuu neljästä osakokeesta, siinä täytyy vastata kysymyksiin ja koe tehdään tietokoneella. Opiskelijat viittasivat myös tutkinnon tarkoitukseen testata kielitaitoa, Suomeen muuttoon ja kielitaidon tarpeellisuuteen Suomessa. Jotkut kuvailivat tutkinnon merkitystä ja siihen liittyviä tunnelmia.

Suuri osa maininnoista koski tutkinnon jakautumista osakokeisiin. Ne ovat puhuminen, puheen ymmärtäminen, kirjoittaminen ja tekstin ymmärtäminen (Työministeriö 2003a). Monet mainitsivat sen, että kokeessa on kirjallinen ja suullinen osio tai sen, että kokeessa täytyy ymmärtää ja vastata kysymyksiin. Kuvailtiin myös tutkinnon suorittamiseen liittyviä teknisiä asioita, esimerkiksi sitä, että se suoritetaan tietokoneella, se kestää 50 minuuttia ja kysymykset esitetään kahteen kertaan. Useat mainitsivat tutkinnon tarkoituksen testata alkeiskielitaidon tasoa tai tutkinnon suorittajan valmiutta puhua suomeksi yksinkertaisimmista asioista.

Yksi näkökulma, jonka tutkinnon suorittajat nostivat esille, oli tutkinnon asema Suomeen muuttoprosessissa ja kielitaidon tarpeellisuus siinä:

(3) Koe tulee läpäistä, jotta voi muuttaa Suomeen. (O18)

(4) Se on tarpeellinen siksi, että sen avulla todetaan kielitaidon vähimmäismäärä. Kielen hallitseminen on erittäin tärkeää, jotta voi opiskella ja sopeutua elämään uudessa maassa. (O23)

Näitä molempia näkökulmia tuli ilmi: koe on edellytys Suomeen pääsylle (esimerkki 3), ja toisaalta kielitaito on edellytys Suomessa pärjäämiselle (esimerkki 4). Mainittiin myös inkeriläisyys ja historialliseen kotimaahan muuttaminen (esimerkki 5). Monet suorittajat kuvailivat tunteitaan tai tunnelmiaan kielitutkinnosta. 
(5) Kurssit auttavat alkuun historialliseen kotimaahansa (Suomeen) tutustumisessa. (O60)

(6) Tiedän, että koe on vaikea. (O30)

(7) Minulle koe tulee olemaan vaikea. (O33)

(8) Puhutaan minun kykyihini nähden liian nopeasti. (O45)

(9) Tiedän, että erityistä huomiota kiinnitetään puheen tuottamisen osaamiseen, mikä nimenomaan tuottaa ongelmia. Lukemista ja kääntämistä opetettiin jo neuvostoaikana koulussa, mutta puhumista ei. Olen ollut monta kertaa Suomessa, mutta suomalaisten kanssa puhuminen tuntuu kovin vaikealta. (O76)

Se, että tutkinto on vaikea, sai useita mainintoja (esimerkit 6-8). Useat vertasivat tutkinnon tasoa omiin taitoihinsa ja peilasivat vaativuutta tätä kautta: minulle [---] vaikea (esimerkki 7), minun kykyihini nähden liian nopeasti (esimerkki 8). Yksi henkilö kontekstoi suomen kielen taitojaan neuvostoajan koulukulttuuriin, jossa lukemista ja kääntämistä opetettiin, mutta puhumista ei (esimerkki 9). Stressivaikutuksen nosti tässä kohdin esille vain kaksi vastaajaa 97:stä. 17 henkilöä sanoi tietävänsä tutkinnosta joko erittäin vähän tai ei juuri mitään. Myös nämä repliikit ovat kiinnostavia, sillä opiskelijat olivat käyneet valmennuskurssia syksystä alkaen, noin seitsemän kuukautta, ja valmennuskurssien opettajat kertoivat, että kielen lisäksi kursseilla harjoiteltiin paljon testitekniikkaa ja juuri kielitutkinnossa tarvittavia tehtävätyyppejä (Martikainen tulossa). Jotkut vastaajat kuitenkin välttelivät vastaamista tähän varsin yleisluontoiseen tutkintoa koskevaan kysymykseen.

(10) En tiedä oikeastaan mitään. Tietoni perustuvat suurimmaksi osaksi [---] kokeen suorittaneiden tuttujen puheisiin. (O3)

Esimerkki (10) osoittaa, että on sellaisia opiskelijoita, jotka luottavat erityisesti vertaisilta saatuun viestintään. Kaikki eivät välttämättä miellä opettajan valitsemia harjoituksia tutkintoon liittyviksi, eivätkä opettajan kuvaukset tutkinnon sisällöstä ja menettelytavoista ole jääneet mieleen.

Tutkinnon suorittajat toivat tutkinnosta esiin siis pääasiassa tutkinnon rakenteeseen ja teknisiin järjestelyihin liittyviä asioita mutta myös tutkinnon tarkoituksen kielitaidon todentamiskeinona ja porttina 
Suomeen. Tunnelmia kuvaavissa vastauksissa mainittiin tutkinnon vaikeus ja tärkeys, mutta stressivaikutus ei korostunut.

\subsection{Kieltä opiskellessa kiinnostus ja kiintymys kasvoivat}

Seuraavaksi tarkastelen sitä, miten aineistossa kuvataan tutkinnon vaikutuksia opiskeluun tutkinnon lähestyessä. Vastanneista 11 sanoi, että opiskelu ei ole muuttunut. Valtaosa kertoi, että tutkinnon lähestyminen vaikuttaa jollain tavalla. Aiemmat tutkimukset ovat osoittaneet monia negatiivisia vaikutuksia, esimerkiksi jännittyneisyyttä, kyllästymistä, toistuvuutta, stressaavaa ilmapiiriä ja kapeiden, vain testissä tarvittavien taitojen harjoittelua (Loumbourdi 2014: 139-144). Tässä tutkimuksessa negatiivisen vaikutuksen mainitsi vain kolme henkilöä. Nämäkään henkilöt eivät arvostelleet kielitutkintoa tai sen aiheuttamia negatiivisia vaikutuksia vaan totesivat, että kieli on hankala (esimerkki 11) tai jopa mahdoton oppia (O17).

(11) Olen alkanut ymmärtää suomen kielen opiskelun vaikeudet. Ymmärrän nyt, että opiskelu vaatii erittäin paljon aikaa, sillä kieli on hankala. (O11)

Yleisvaikutelma vastauksissa on kuitenkin kielenopiskelu- ja myös tutkintomyönteinen. Muissa tutkimuksissa opiskelijoiden nimeämiä myönteisiä vaikutuksia ovat olleet tarkkuuden ja kieliopin hallinnan parantuminen, opiskelumotivaation lisääntyminen, lukemisen lisääntyminen ja opiskelun kurinalaisuus ja aikataulujen mukaisuus (Loumbourdi 2014: 140). Tässä tutkimuksessa monet mainitsivat opiskelunsa tehostuneen.

(12) Kyllä. Suhtaudun vastuullisemmin. Kertaan enemmän joka päivä. (O49)

(13) Kyllä, on muuttunut. Vaadin itseltäni nykyään enemmän. (O96)

(14) On muuttunut parempaan suuntaan. Haluan oppia puhumaan ja ymmärtämään vielä enemmän. $(\mathrm{O} 24)$ 
Näissä esimerkeissä näkyvät opiskelumäärän lisääntyminen (esimerkki 12) ja itseltä vaatimisen lisääntyminen (esimerkit 13 ja 14). Useissa muissakin vastauksissa ilmeni vastuun lisääntyminen omasta oppimisesta. Toinen toistuva ilmaus oli innokkuuden lisääntyminen: halu opiskella kieltä lisää, halu oppia puhumaan ja ymmärtämään enemmän. Tarkkuuden lisääntymiseen liittyviä kommentteja esiintyi myös.

(15) Ajattelen yhä enemmän, miten sanon asioita oikein. (O74)

(16) Haluan opiskella sitä lisää, jotta pystyisin tulevaisuudessa puhumaan suomea täydellisesti. (O4)

Selviytymistason kielenoppijalta ei tutkinnossa edellytetä virheettömyyttä, mutta esimerkin (15) sanon asioita oikein voi kuvastaa tarkkuuden lisäksi tai sijasta myös kielenoppimisen vaihetta, jossa kielen rakenteet jäsentyvät. Esimerkissä (16) kuvastuu henkilön suuntautuminen tulevaisuuteen, jolloin hän edelleen jatkaa suomen kielen opiskelua ja puhuu suomea täydellisesti. Aineistossani viisi opiskelijaa sanoi kielen opiskelun olevan kyselyn toteutusaikaan helpompaa kuin aiemmin (esimerkit 17 ja 18).

(17) Suomen kieli oli minulle jo ennen kursseja erittäin vaikea. Kun aloitin opiskelun, vaikeudet alkoivat kaikota. (O27)

(18) Kieli on vaikea, mutta opiskelun myötä se muuttuu entistä ymmärrettävämmäksi ja loogisemmaksi. (O19)

Kysely toteutettiin noin kolme viikkoa ennen kielitutkintoa, ja näiden käsitysten (esimerkit 17 ja 18) perusteella ainakin joidenkin opiskelijoiden kohdalla on onnistuttu pääsemään kielen opinnoissa sopivaan vaiheeseen tutkinnon suorittamista ajatellen.

Monet kuvailivat kielen opiskelun muuttuneen mielenkiintoisemmaksi, kun tutkintoon oli vain vähän aikaa. Alkuvaiheen suurimmat haasteet olivat ohi (esimerkki 19):

(19) Joka kerta kun saa tietää jotakin uutta ja mielenkiintoista, opiskelusta tulee yhä vain mielenkiintoisempaa, ja haluaa opiskella suomen kieltä lisää. (O1)

(20) Esiintyi enemmän kiinnostuneita. (O28S) 
Useat vastauksista ovat niin lyhyitä, että ne jäävät hiukan arvoituksellisiksi tai epätäsmällisiksi. Esimerkki (20) on niin tiivis, että siitä ei näy, onko kiinnostus syntynyt kieltä kohtaan vai jotakin tutkintoon liittyvää kohtaan. Tämä oli yksi harvoista suomenkielisistä vastauksista, ja vastauksen niukkuus voi johtua myös kielitaidon rajallisuudesta. Joka tapauksessa noin kaksi kolmasosaa vastanneista kuvasi muutosta positiiviseksi, joko niin että opiskelu on tehostunut tai muuttunut mielenkiintoisemmaksi tai jopa muuten mieluisammaksi. Lähes kolmessakymmenessä vastauksessa suomen kieltä tai sen opiskelua kuvailtiin rakkaaksi, kauniiksi ja sellaiseksi, että sitä haluaa oppia:

(21) On herännyt suuri kiinnostus kieltä kohtaan. Haluan oppia sitä lisää. On mielenkiintoista kuunnella suomenkielistä puhetta. (O58)

(22) Rakastan suomen kieltä ja kaikkea, mikä liittyy Suomeen. (O70)

(23) Suomen kielestä on tullut osa elämääni, ja siksi haluaisin osata sitä entistä paremmin. (O39)

Esimerkissä (21) näkyy myönteinen suhtautuminen sekä kieltä että myös sen opiskelua kohtaan. Monissa vastauksissa mainittiin jompikumpi, lämmin suhtautuminen joko kieltä tai sen opiskelua kohtaan. Vastauksissa toistuu myös ilmaisun taloudellisuus, kuten edellä esimerkissä (20): vastaukset ovat usein lyhyitä, virkkeen parin mittaisia. Vastausta ei ole täsmennetty tai eritelty. Tämä niukkuus on tyypillinen kyselyaineiston ilmiö (Dörnyei 2009: 7-10). Aineiston perusteella voi kuitenkin todeta, että kaikkein lämpimimmät tunteet kohdistuvat juuri suomen kieltä ja kulttuuria kohtaan, mutta myös opiskelua on pidetty mielekkäänä ja tunteet ovat muuttuneet positiivisempaan suuntaan opiskelun myötä.

Tutkinnon suorittajat ottivat kyselyssä kantaa myös siihen, onko Dipaki-tutkinto hyvä tapa mitata kielitaitoa. 74 vastaajaa 97:stä piti Dipaki-tutkintoa hyvänä, 11 ei pitänyt ja 12 oli jättänyt vastaamatta (taulukko 4). 
Tauluкко 4. Onko Dipaki-tutkinto hyvä tapa mitata suomen kielen taitoa?

\begin{tabular}{|l|c|c|}
\hline Vastaus & N & Prosentti \\
\hline Kyllä & 74 & $76,3 \%$ \\
\hline Ei & 11 & $11,3 \%$ \\
\hline Tyhjä & 12 & $12,4 \%$ \\
\hline Yhteensä & 97 & $100 \%$ \\
\hline
\end{tabular}

Niistä, jotka vastasivat kielteisesti, muutamilla oli myös sanallinen vastaus. Kolme arveli, että perinteinen haastattelu olisi parempi. He eivät valitettavasti perustelleet vastaustaan. Yksi sanoi, että koe ei motivoi häntä kielen opiskeluun ja yksi vastasi, että yksi lukuvuosi on liian lyhyt aika kielen oppimiseen. Tämä vastaus liittyy kielitutkinnon vaikeustasoon, siihen keskusteluun, mille kielitaidon tasolle yhden lukuvuoden aikana voi päästä.

(24) Kokeeseen valmistavat kurssit (suomen kielen kurssit) olivat jo itsessään erittäin tehokkaita. Me olisimme opiskelleet ja puhuneet suomea ennen Suomeen muuttoa tarpeeksi muutenkin. Tämä koe aiheuttaa kamalaa stressiä!! (O70)

Muutamat, myös sellaiset, jotka pitivät Dipakia hyvänä tapana mitata kielitaitoa, vastasivat, että kielitutkinto aiheuttaa stressiä (esimerkki 24). Jotkut arvioivat, että jännityksen vuoksi he saattavat pärjätä tutkinnossa todellista kielitaidon tasoaan heikommin.

Tutkinnon stressaavuus ja jännittävyys on merkittävä ilmiö sekä yksilön että myös kielitutkinnon kannalta, sillä jännittäminen voi vaikuttaa tutkinnossa suoriutumiseen ja siten tutkinnon validiteettiin (Messick 1996: 243; Stricker \& Attali 2010: 1). Siksi kyselyn yhtenä teemana oli jännittäminen. Yli 60 prosenttia kyselyyn vastanneista kertoi tutkinnon jännittävän erittäin paljon tai melko paljon (taulukko 5). 
TAULUкко 5. Jännittääkö Dipaki-tutkinto?

\begin{tabular}{|l|c|c|}
\hline Vastaus & N & Prosentti \\
\hline Ei yhtään & 4 & $4,12 \%$ \\
\hline Vähän & 12 & $12,37 \%$ \\
\hline Jonkin verran & 17 & $17,53 \%$ \\
\hline Melko paljon & 31 & $31,96 \%$ \\
\hline Erittäin paljon & 33 & $34,02 \%$ \\
\hline Yhteensä & 97 & $100 \%$ \\
\hline
\end{tabular}

Useat kuvailivat jännityksen vaikutusta huolena siitä, pystyykö toimimaan tutkinnossa omalla tasollaan tai riittääkö oma kielitaito tutkinnon läpäisemiseen. Teknisiä ongelmia tai lyhyttä vastausaikaa murehti kolme henkilöä. Neljä vastaajaa nosti tässä esiin tutkinnon ratkaisevan merkityksen: siitä riippuu perheen tulevaisuus, Suomeen muutto. Huoli oli siinä mielessä aiheellinen, että tutkinnon suoritti hyväksytysti 78,5 prosenttia osallistujista vuonna 2016. Kun osallistujia oli kaikkiaan 251, sai hylätyn arvioinnin 54 henkilöä. Heidän vaihtoehdoikseen jäi joko jättää kesken paluumuuttoprosessi, siis Suomen oleskeluluvan hakeminen inkeriläisstatuksella, tai suorittaa Yleinen kielitutkinto ja saada siitä vastaava arvosana, vähintään taitotasoa $\mathrm{A} 2$ vastaava taso puhumisessa ja jossakin muussa osataidossa (Laine 2015).

Kielitutkinnon vaikutuksista opiskeluun jäi opiskelijoiden vastausten perusteella kokonaisuudessaan myönteinen vaikutelma: opiskelijat suhtautuivat suomen kielen opiskeluun ja lähestyvään kielitutkintoon myönteisesti. Se, että yli 70 prosenttia vastanneista kertoi, että Dipakitutkinto on hyvä tapa mitata kielitaitoa, on suuri osuus. Myönteisyyteen voi toki ainakin osittain vaikuttaa se, että aineisto kerättiin luokkahuoneessa mahdollisesti opettajien nähden. Opiskelijoiden myönteinen suhtautuminen kielen oppimiseen ja opiskeluun pohjautuu varmasti ainakin osittain siihen työhön, jota valmennuskurssien opettajat kurssien aikana tekivät. He pitivät kielitutkintoa omaa työtään tukevana, opiskelijoita motivoivana ja opetustyötä raamittavana (Martikainen tulossa). He ovat välittäneet tietoa kielitutkinnosta ja ohjanneet opiskelijoita kurssin 
ajan. Näin opettajien käsitykset tutkinnosta ovat voineet vaikuttaa myös opiskelijoiden käsityksiin. Suuri osa kyselyyn vastanneista opiskelijoista toi ilmi kiintymyksen, jopa rakkauden tunteita suomen kieltä, kulttuuria ja niiden opiskelua kohtaan. Nämä maininnat olivat selvästi yleisempiä kuin stressivaikutusta koskevat maininnat.

\subsection{Suullisista harjoitukset ovat osa kielen opiskelua}

Dipaki-kielitutkintoon liittyvä tavoitteiden asettaminen oli työryhmän perustamisvaiheessa varsin yleisluontoista (ks. luku 1). Työryhmän tehtävinä mainittiin kielitutkinnon kehittäminen ja toimeenpano sekä myös kielitutkintoon liittyvän koulutuksen koordinointi (Työministeriö 2003b). Lisäksi työryhmän asiantuntijajäsenet mainitsivat kielitutkinnon tavoitteeksi selviytymiskielitaidon kehittämisen erityisesti puhumisen osalta. Asiantuntijat nostivat esiin myös kielitutkinnon keinona testata luotettavalla tavalla, osaavatko inkeriläisstatuksella oleskelulupaa hakevat henkilöt suomea siten, kuin ulkomaalaislaissa vuodesta 2003 alkaen edellytettiin (Martikainen tulossa).

Sitä, onko koulutuksessa tapahtunut tavoitteiden mukaista tai yleensäkään muutosta, ei opiskelijoiden kyselyvastauksista näe, sillä he ovat osallistuneet paluumuuttovalmennukseen vain kerran. He kuvailivat vastauksissaan tilannetta kurssilla omana opiskeluvuotenaan 2015-2016. Nämä kuvaukset ovat myönteisiä, kuten jo aiemmin on todettu. Kyselyn vastanneista 32 kehui kurssia muun muassa ilmauksilla erinomainen, mielenkiintoinen ja hyvin rakennettu. Jotkut vastaajat harmittelivat sitä, että valmennus kesti liian vähän aikaa, vain yhden lukuvuoden, kahtena iltana viikossa. Osa vastanneista esitti koulutuksen kehittämisideoita, mutta mitkään ideoista eivät toistuneet eri vastaajilla. Yksi toivoi käännöstehtäviä, toinen enemmän oppitunteja venäjäksi, yksi etäkurssia ja yksi lisää suullisia harjoituksia.

Yksi tutkinnolle asetettu tavoite oli suullisen kielitaidon kehittäminen. Puhumisen keskeisyys näkyi aineistossani siten, että monet mainitsivat puhumisen harjoittelun tärkeänä kotitehtävätyyppinä ja kokeeseen 
valmistautumisen tapana. Sosiaalisina verkostoina nimettiin perhe, erityisesti Suomessa asuvat sukulaiset, joiden kanssa pidettiin yhteyttä esimerkiksi Skype-puheluiden avulla (esimerkit 25 ja 26).

(25) Pyrin puhumaan kieltä päivittäin (perheenjäsenteni kanssa) eri sovellusten avulla. (O4)

(26) Puhun Suomessa asuvien sukulaisteni kanssa. (O54, O76)

Monissa vastauksissa ilmeni sosiaalisten suhteiden käyttäminen kielen opiskelussa, tietotekniikan hyödyntäminen ja yleensäkin itsenäinen ja aktiivinen suhtautuminen omaan oppimiseen. Kieltä harjoiteltiin myös muilla tavoilla kuin pelkästään opettajan antamilla tai osoittamilla tehtävillä.

Opiskelutapoina mainittiin kuitenkin yhtä paljon tai jopa useammin kirjat ja lukeminen, äänimateriaalin kuuntelu, elokuvien katselu ja kurssimateriaalin kertaaminen, siis tehtävätyypit, joissa painottuivat kirjallisen viestinnän ja puheen ymmärtämisen taidot. Ilman voimakasta panostusta puhumisen opetuksen kielenoppijat tuskin olisivat kuitenkaan näin selkeästi tiedostaneet sosiaalisissa suhteissa tarvittavaa puhetaitoa keskeisenä kielitaidon ja myös sen harjoittelun osana. Samoin opettajien haastatteluissa puhuminen korostui vahvasti (Martikainen tulossa).

Kun kielenopiskelijat ovat vasta menossa Dipaki-tutkintoon, heidän on vaikea kommentoida tutkinnon luotettavuutta kielitaidon arvioinnissa. Kyselyyn vastanneet toivat esille huolen siitä, miten jännittäminen vaikuttaa tutkinnossa suoriutumiseen. Merkille pantavaa kuitenkin on, että suoranaisia epäilyjä tutkinnon luotettavuudesta ei ollut lainkaan, ja suuri osa vastanneista oli sitä mieltä, että Dipaki-tutkinto on hyvä tapa testata kielitaitoa (taulukko 4). Lähes 30 vastannutta perusteli tutkintoa kielitaidon todentamisella. Muutamat kyseenalaistivat kielitaidon arvioinnin sinänsä mutta pitivät kielenopetusta tarpeellisena.

Kielitutkinnolle asetettujen tavoitteiden toteutumista voidaan opiskelijoilta kerätyn aineiston perusteella arvioida vain osittain. Puhetaidon ja opetuksen kehittämisen lisäksi tavoitteena oli myös tutkintojärjestelmän 
kehittäminen ja seuranta sekä kielitutkinnon Suomeen-muuttoon mahdollisesti liittyvien vaikutusten seuranta (Työministeriö 2003b). Näistä vaikutuksista ei opiskelijoille suunnatulla kyselyllä saatu tietoa.

\section{Pohdinta}

Inkeriläisten paluumuuton alkuvuosina vaadittiin voimakkaampia viranomaistoimenpiteitä paluumuuton ohjaukseen, ja suomen kielen taidon vaatimus lainsäädännössä oli yksi keino (Martikainen 2016). Kielitutkinnon suorittamisvaatimus on painokas tapa osoittaa, että kielitaitoa edellytetään. Se on ollut tämän tutkimuksen perusteella myös varsin tehokas keino. Sitä, mitä testataan, pidetään arvokkaana ja tärkeänä (Cheng 2014: 2482). Washback-vaikutuksen kannalta kaikkein oleellisin ajanjakso on juuri ennen kielitutkintoa, koska silloin oletukset tutkinnossa vaadituista taidoista vaikuttavat kielen opiskeluun ja asennoitumiseen opiskelua kohtaan.

Kokoan seuraavaksi vastaukset alussa esittämiini kolmeen tutkimuskysymykseen. Opiskelijoiden käsitykset tutkinnosta ja suomen kielen opiskelusta olivat myönteisiä (tutkimuskysymys yksi). Kyseessä oli merkitykseltään painava high stakes -tutkinto, jonka läpäisemisestä saattoi riippua mahdollisuus muuttaa Suomeen. Kaikki tutkintoon osallistuneet eivät tutkintoa läpäisseet, joten osa heistä joutui muuttamaan suunnitelmiaan tutkinnossa epäonnistumisen takia. Vuonna 2016 heitä oli 21,5 prosenttia, siis yli viidesosa tutkinnon suorittaneista. Tästä huolimatta tutkimukseen osallistuneet pitivät tutkintoa hyvänä tapana testata suomen kielen taitoa. Tutkinnon luotettavuutta ei epäilty, ja tutkintoon valmentautuminen kurssilla oli innostanut monia kielen opiskeluun, jota he sanoivat jatkavansa myös tutkinnon jälkeen. Kansainvälisissä tutkimuksissa suhtautuminen kielitutkintoon on ollut neutraalia, lievästi positiivista tai jopa lievästi negatiivista (Stricker \& Attali 2010). Inkeriläisten kohdalla suhtautuminen kallistuu selkeästi positiiviselle kannalle.

Muissa tutkimuksissa mainittiin kielitutkinnon aiheuttavan kielenopetukseen negatiivisia vaikutuksia: stressaavaa ilmapiiriä ja kapeiden, 
vain testissä tarvittavien taitojen harjoittelua (Loumbourdi 2014: 139144). Näitä ei mainittu Dipaki-tutkintoon valmentavalla kurssilla lainkaan. Tutkinnon aiheuttama stressivaikutus mainittiin, mutta stressaavuuden ei koettu siirtyneen opetukseen, vaan kurssien ilmapiiriä kiiteltiin hyväksi. Tätä eroa ei voi selittää (ainakaan yksistään) kielitutkinnon piirteillä, vaan myönteiset vaikutukset ovat mahdollisesti vahvistuneet opettajien täydennyskoulutuksen ja tätä kautta kurssin sisällön ja ilmapiirin kautta. Valmennuskurssien opettajat ovat saaneet aivan tutkinnon alkuajoista lähtien koulutusta, oppimateriaalia ja muuta tukea, joka on osaltaan vaikuttanut opetuskäytänteisiin (Mielonen 2014; 2015 ; 2016). Kielitutkinto on ollut ainakin osa innovaatiota (Henrichsen 1989), joka on vaikuttanut näihin opiskelumyönteisiin käsityksiin. Opettajien myönteinen suhtautuminen on nähtävästi välittynyt myös opiskelijoille. Wallin (2000: 503) mukaan kaikkein jähmeintä opetuksen innovaation aiheuttama muutos on asenteiden ja käyttäytymisen tasolla. Tässä tutkimuksessa ei aineiston rajauksen vuoksi näy juurikaan vaikutuksia opetuksen sisältöön tai opetusmenetelmiin, mutta opiskelijoiden käsitysten myönteisyys käy ilmi.

Inkeriläisten paluumuuttovalmennuksen ja kielitutkinnon kohdalla monet opiskelijat kuvailivat sitä, kuinka heidän kielen opiskelunsa on muuttunut valmennuskurssin aikana ja kielitutkinnon lähestyessä myönteiseen suuntaan: opiskelu on tehostunut, suomen kieli on mielenkiintoisempaa ja helpompaa kuin ennen ja monilla suhtautuminen suomen kieltä ja opiskelua kohtaan on muuttunut lämpimämmäksi (tutkimuskysymys kaksi). Puhumisen harjoittelusta on tullut osa opiskelukäytäntöjä. Näiden kuvausten perusteella voi sanoa, että tutkinnon vaikutus kielen opiskeluun on ollut voimakasta. Se on vaikuttanut moniin opiskelijoihin ja vaikuttanut heihin voimakkaasti. Aineistosta näkyy, että kielen opiskelusta on tullut tapa, siihen on valmiuksia ja suomen kielen ja kulttuurin merkitys on vahvistunut. Tätä muutosta voisi pitää kielitutkinnon washback-vaikutuksena (tutkimuskysymys kolme). Jatkuuko tämä myönteinen vaikutus, ei tässä tutkimuksessa selviä. Toisaalta on huomioitava aineiston keruun konteksti, joka on osaltaan saattanut 
vaikuttaa tuloksiin. Kun kyselyihin vastattiin luokkatilanteessa ja kyselyn vastaukset saattoivat joutua opettajan käsiin, vastausten painopiste saattoi miellyttämishalun ja elämäntilanteen vuoksi siirtyä myönteisemmälle kannalle, kuin mitä ne muutoin olisivat olleet.

Tutkimusaineisto koottiin vaiheessa, jolloin kielitutkinto oli vielä edessä. Vastatessaan henkilöt eivät siis vielä tienneet, läpäisevätkö he tutkinnon vai eivät. Joitakin vastaajista tutkinto stressasi kovasti, ja jotkut jopa arvelivat, etteivät pysty näyttämään parasta kielitaitoaan tutkinnossa jännityksen vuoksi. Loumbourdin tutkimuksessa (2014) tutkinnon suorittamisen jälkeen kerätyssä aineistossa opiskelijoiden näkemykset tutkinnosta painottuivat tutkintomyönteiselle puolelle enemmän kuin ennen tutkintoa kerätyssä aineistossa. Näkemykset tutkinnosta saattavat muuttua voimakkaasti tutkinnon suorittamisen jälkeen ja sen jälkeen, kun tutkinnon suorittamisesta on kulunut jonkin verran aikaa (Van Avermaet \& Pulinx 2014: 9). Toisaalta eri henkilöt painottavat omassa onnistumisessaan hyvin erityyppisiä asioita: toiset henkilökohtaisia, toiset ulkoisia, toisaalta kontrolloitavia, toisaalta kontrolloimattomia tekijöitä (Williams \& Burden 1997: 105). Tutkinnossa onnistumisella voi olla merkittäviä vaikutuksia yksilön elämään ja kielen opiskeluun jatkossa. Tutkinnon jälkeen monet yksilötekijät, esimerkiksi Suomeen-muuttoon liittyvät asiat, saattavat vaikuttaa käsityksiin kielitutkinnon merkityksestä. Kielitutkinnon piirteillä on tällöin vähemmän merkitystä kuin ennen tutkintoa kerätyssä aineistossa.

Tämän tutkimuksen avulla ei saada tietoa siitä, vastasiko kielitutkinto henkilöiden ennakkokäsityksiä eikä siitä, eroavatko tutkinnossa epäonnistuneiden näkemykset sinä onnistuneiden näkemyksistä. Hylätyn arvioinnin saaneilla ei ollut mahdollisuutta muuttaa Suomeen inkeriläisstatuksella, vaikka heillä syntyperänsä puolesta olisi siihen ollut oikeus. Näitä hylätyn arvioinnin saaneita on koko inkeriläistutkinnon järjestämisaikana ollut kaikkiaan 1057, siis 19,3 prosenttia kaikista tutkinnon suorittajista. Sekä hylätyn arvioinnin saaneiden että myös tutkinnon hyväksytysti suorittaneiden näkemykset tutkinnon vaikutuksista olisivat kiinnostavaa kuultavaa. 
Lopuksi voi vielä pohtia, olisiko tätä opiskelijoiden kuvaamaa merkittävää myönteistä muutosta kielenopiskelussa tapahtunut valmennuskurssilla ilman kielitutkintoa. Tutkinto on ollut ulkoinen pakko ja siten motivaattori. Monet opiskelijat vakuuttivat, että he jatkavat suomen kielen opiskelua myös tutkinnon jälkeen, sisäisen motivaation ansiosta. Ainakin tutkinto on ollut keino osoittaa, että suomen kielen taidon kehittäminen on osa paluumuuttoprosessia, johon valmennuksen aikana on kannustettu ja johon on annettu valmiuksia. Kielen opiskelusta on tullut tapa; siitä on tullut osa elämää.

\section{Lähteet}

Bachman, Lyle, Adrian Palmer 1996. Language Testing in Practice. Oxford: Oxford University Press.

Cheng, Liyang 2008. Washback, impact and consequences. - Elana Shohamy, Nancy Hornberger (Eds.), Encyclopedia of Language and Education, Vol. 7. New York: Springer Science + Business Media LLC, 2479-2494.

Cheng, Liyang 2014. Consequences, impact and washback. - Anthony Kunnan (Ed.), The Companion to Language Assessment. New York: John Wiley \& Sons, Inc., 2479-2494.

Davydova, Olga 2002. Interaktiivista identiteettipeliä - havaintoja paluumuutosta Suomeen. - Sirkka Laihiala-Kankainen, Sari Pietikäinen, Hannele Dufva (Toim.), Moniääninen suomi. Kieli, kulttuuri ja identiteetti. Jyväskylä: Jyväskylän yliopisto. Soveltavan kielentutkimuksen keskus, 154-168.

Dörnyei, Zoltán 2009. Questionnaires in Second Language Research. Abingdon: Routledge.

Griffiths, Carol 2008. Lessons from Good Language Learners. Cambridge: Cambridge University Press. https://doi.org/10.1017/CBO9780511497667

Hawkey, Roger 2006. Impact Theory and Practice: Studies of the IELTS test and Progetto Lingue 2000. Cambridge: Cambridge University Press.

Henrichsen, Lynn1989. Diffusion of Innovations in English Language Teaching: The ELEC Effort in Japan 1956-1968. New York: Greenwood Press.

Huhta, Ari, Raili Hildén 2016. Kielitutkinnot ja muu laajamittainen kielitaidon arviointi Suomessa. - Ari Huhta, Raili Hildén (Toim.), Kielitaidon arviointitutkimus 2000-luvun Suomessa. AFinLA-e. Soveltavan kielitieteen tutkimuksia 9, 3-12. 
Iskanius, Sanna 2006. Venäjänkielisten maahanmuuttajaopiskelijoiden kieli-identiteetti ['Language and identity of Russian-speaking students in Finland']. Jyväskylä studies in humanities 51. Jyväskylä: Jyväskylän yliopisto.

Kalaja, Paula 2015. A review of five studies on learner beliefs about second language learning and teaching: Exploring the possibilities of narratives. - Teppo Jakonen, Juha Jalkanen, Terhi Paakkinen, Minna Suni (Toim.), Kielen oppimisen virtauksia. Flows on language learning. AFinLAn vuosikirja 2015. Suomen soveltavan kielitieteen yhdistyksen julkaisuja 0 (73), 21-38.

Kalaja, Paula, Ana Maria F. Barcelos, Mari Aro, Maria Ruohotie-Lyhty 2015. Beliefs, Agency and Identity in Foreign Language Learning and Teaching. Basingstoke: Palgrave Macmillan. https://doi.org/10.1057/9781137425959

Kärkkäinen, Kaija, Jani Lankinen 2008. Computer-delivered test of Finnish for Ingerian returnees. The 5th Annual EALTA Conference 8th-11th May 2008. Hellenic American Union, Athens, Greece. http://www.ealta.eu.org/ conference/2008/docs/posters/Dipaki_handout.pdf (5.6.2016).

Laine, Marianne 2015. Paluumuuttotiimin päällikkö. Sähköpostiviesti 2.11 ['Email'].

Loumbourdi, Lambrini 2014. The Power and Impact of Standardized Tests: Investigating Washback on Language Exams in Greece. Frankfurt/Main: Peter Lang.

Maahanmuuttovirasto 2015a. Kielitutkinto paluumuuttajille. http://www.migri.fi/ paluumuutto/paluumuuttaja_entisen_neuvostoliiton_alueelta/hakemuksen_jattamisen_edellytykset/kansallisuudeltaan_suomalainen/kielitutkinto (17.6.2016).

Maahanmuuttovirasto 2015b. Raportti inkerinsuomalaisten paluumuuttajien kielitutkinnoista vuosilta 2003-2014. Julkaisematon raportti.

Maahanmuuttovirasto 2016. Raportti inkerinsuomalaisten paluumuuttajien kielitutkinnoista vuosilta 2005-2016. Julkaisematon raportti.

Martikainen, Minna 2016. Inkeriläisten paluumuuttajien kielitutkinnon synty keskustelussa. - Ari Huhta, Raili Hildén (Toim.), Kielitaidon arviointitutkimus 2000-luvun Suomessa. AFinLA-e. Soveltavan kielitieteen tutkimuksia 9, 44-67.

Martikainen, Minna (tulossa). Kielitutkinto ohjaa opetusta ja kannustaa opiskeluun.

Messick, Samuel 1996. Validity and washback in language testing. - Language Testing 13 (3), 241-256. https://doi.org/10.1177/026553229601300302

Mielonen, Riitta 2014. Inkerinsuomalaisten paluumuuttovalmennuskoulutus. Lukuvuosi 2013-2014 Pietarissa, Hatsinassa ja Petroskoissa. Loppuraportti. Etelä-Kymenlaakson ammattiopisto. Julkaisematon raportti. 
Mielonen, Riitta 2015. Paluumuuttovalmennuksen toteutuksesta. Haastattelu 15.7.2015.

Mielonen, Riitta 2016. Inkerinsuomalaisten paluumuuttovalmennuskoulutuksen viimeinen loppuraportti lukuvuodelta 2015-16 Pietarissa ja Petroskoissa. Etelä-Kymenlaakson ammattiopisto. Julkaisematon raportti.

Moore, Stephen, Richard Stroupe, Paul Mahony 2009. Perceptions of IELTS in Cambodia: A case study of test impact in a small developing country. J. Osbourne (Ed.), IELTS Reports Vol. 13. Melbourne/Manchester: IELTS Australia and British Council, 293-401.

Neittaanmäki, Reetta, Tuija Hirvelä 2014. Yleisten kielitutkintojen osallistujat taustatietojen valossa. - Tarja Lebley, Tiina Lammervo, Mirja Tarnanen (Toim.), Yleiset kielitutkinnot 20 vuotta. Raportit ja selvitykset 2014: 16. Helsinki: Opetushallitus, 46-60.

Potter, Jonathan, Margaret Wetherell 1987. Discourse and Social Psychology: Beyond Attitudes and Behaviour. London: Sage.

Rubin, Joan 1975. What the "Good language Lerner" can teach us. - TESOL Quarterly 9 (1), 41-51. https://doi.org/10.2307/3586011

Stricker, Lawrence, Yigal Attali 2010. Test Takers' Attitudes about the TOEFL iBM. ETS Research Report Series 13. Princeton: ETS.

Struck-Soboleva, Julia 2006. Controversies surrounding language policy and the integration process of Russian Germans in Germany. - Language and Intercultural Communication 6 (1), 57-75. https://doi.org/10.1080 /14708470608668908

Tuomi, Jouni, Anneli Sarajärvi 2002. Laadullinen tutkimus ja sisällönanalyysi. Helsinki: Tammi.

Työministeriö 1998. Inkerinsuomalaisten maahanmuutto Suomeen 1990-luvulla. Hallituksen selonteko eduskunnan ulkoasiainvaliokunnalle. Työhallinnon julkaisu 215. Helsinki: Työministeriö.

Työministeriö 2003a. Inkerinsuomalaisten paluumuuttajien kielitestin perusteet. Helsinki: Työministeriö.

Työministeriö 2003b. Ulkomaalaislain 18 a §:n toimeenpanoa koordinoivan työryhmän asettaminen. Asiakirja 1.4.2003. 635/021/2003TM. Helsinki: Työministeriö.

Wall, Dianne 1997. Impact and washback in language testing. - Caroline Clapham, David Corson (Eds.), Encyclopedia of Language and education. Dordrecht: Kluwer Academic, 291-302.

Wall, Dianne 2000. The impact of high-stakes testing on teaching and learning: Can this be predicted or controlled? - System 28, 499-509. https://doi. org/10.1016/S0346-251X(00)00035-X 
Wall, Dianne, Tania Horák 2006. The impact of changes in the TOEFL examination on teaching and learning in Central and Eastern Europe. Phase 1, the baseline study. - ETS Research Report Series 1, i-199. https://doi. org/10.1002/j.2333-8504.2006.tb02024.x

Wall, Dianne, Tania Horák 2008. The impact of changes in the TOEFL examination on teaching and learning in Central and Eastern Europe. Phase 2, coping with change. TOEFL iBT Research Report No. iBT-05. - ETS Research Report Series 2, i-105. https://doi.org/10.1002/j.2333-8504.2008.tb02123.x

Van Avermaet, Piet, Reinhilde Pulinx 2014. Language testing for immigration to Europe. The Companion to Language Assessment. I:3:22,376-389. John Wiley \& Sons, Inc. http://dx.doi.org/10.1002/9781118411360.wbcla132

Wenden, Anita 1991. Learner Strategies for Learner Autonomy: Planning and Implementing Learner Training for Language Learners. Englewood Cliffs, NJ: Prentice Hall.

Williams, Marion, Robert L. Burden 1997. Psychology for Language Teachers: A Social Constructivistic Approach. Cambridge: Cambridge University Press.

Yleisradio 1990. Presidentti Mauno Koiviston haastattelu. Yleisradio 10.4.1990. https://yle.fi/aihe/artikkeli/2006/11/02/presidentti-mauno-koivistonkommentti-inkerilaisista (28.1.2017). 


\section{Liite 1. Kysely}

Hyvä paluumuuttovalmennuksen opiskelija / Уважаемый студент подготовительных курсов!

Pyydän sinua vastaamaan seuraaviin kysymyksiin, jotka koskevat Dipaki-tutkintoa. Voit vastata suomeksi tai venäjäksi. Oikeita tai toivottuja vastauksia ei ole, vaan haluan saada tietoa opiskelijoiden ajatuksista. Tämä kysely liittyy Jyväskylän yliopiston väitöskirjatutkimukseeni, jossa selvitän Dipaki-tutkinnon vaikutuksia. / Просим вас ответить на следующие вопросы, касающиеся исследования “ДИПАКИ”. Язык для ответов Вы можете выбрать либо русский, либо финский.Правильных или неправильных ответов нет в этом опросе.Сам опрос является частью моей диссертации в университете Ювяскюля. На тему “Влияние “ДИПАКИ” экзамена.”

Lisätietoja / Доп. сведения XXXXXXXXXXXX@XXXXXXXX.XX

\section{Kysely / Oпрос}

1. Mitä tiedät Dipaki-tutkinnosta? Voit kertoa niin monta asiaa kuin haluat. / Что Вы знаете об экзамене “ДИПАКИ”? Можете отвечать в свободной форме.

2. Kuinka paljon opiskelet suomea viikossa paluumuuttovalmennuskurssin lisäksi? / Как много часов Вы уделяете изучению финского языка в неделю? Кроме изучения его на курсах.

$\square \quad$ Vähemmän kuin 1 tunti / Меньше 1 часа

$\square \quad$ 1-2 tuntia / 1-2 часа

$\square \quad$ 3-4 tuntia / 3-4 часа

$\square \quad$ Enemmän kuin 4 tuntia / больше 4 часов

3. Millä tavalla opiskelet itse suomea? Mitä teet? / Как Вы изучаете финский язык? Какими способами пользуетесь? 
4. Jännittäkö Dipaki-tutkinto? / Переживаете ли Вы из-за будущего экзамена?

$\square$ Ei yhtään / Ни сколько

$\square$ Vähän / Слегка

$\square$ Jonkin verran / Чуть-чуть

$\square$ Melko paljon / Сильно

$\square$ Erittäin paljon / Очень сильно

5. Jos vastasit, että tutkinto jännittää, kerro, millä tavalla jännitys näkyy. / Если Вы ответили “Очень сильно”,то опишите как это проявляется.

6. Onko opiskelusi muuttunut viime aikoina, kun tutkintoon on vain vähän aikaa? Miten? / Изменилось ли Ваше отношение к изучению финского в последнее время? Каким образом?

7. Onko Dipaki-tutkinto hyvä tapa mitata suomen kielen taitoa? / Ha сколько действенным способом в изучении финского является сдача “ДИПАКИ” экзамена?

$\square$ Kyllä on. / Да.Действенный

$\square \quad$ Ei ole. / Нет.Напрасен

$\square$ Miksi?/ Почему?

8. Mitä muuta haluat sanoa paluumuuttovalmennuksesta tai Dipaki-tutkinnosta? / Что бы Вы хотели бы добавить о самом курсе для "возвращающихся на историчесскую Родину и о самом “ДИПАКИ” экзамене?

\section{Taustatietoja / Основные данные}

Olen / Я

$\square$ Nainen / Женщина

$\square$ Mies / Мужчина
Kuinka vanha olet? / Мой возраст

$\square \quad$ 15-25-vuotias / 15-25 лет

26-40-vuotias / 26-40 лет

$\square$ 41-65-vuotias / 41-60 лет

yli 66-vuotias / свыше 66 лет

Kiitos paljon avustasi! / Огромное спасибо за ответы! 


\title{
A high-stakes language exam: A gate to Finland, a stepping stone to Finnish
}

\author{
MINNA MARTIKAINEN \\ University of Jyväskylä
}

This is a study on perceptions of Ingrian students preparing for a language exam. Ingrians are ethnic Finns who have been living in Russia and Estonia for many generations. In order to immigrate to Finland on the basis of Finnish origin they had to prove Finnish language skills at the Common European Framework level A2. In this paper, I analyze how students describe the influence of the exam on how they study Finnish. The data consists of students' questionnaire responses $(\mathrm{n}=97)$. The method is content analysis. On the basis of this data it seems that the students were aware of the structure and the computer based nature of the exam. They also knew that passing the exam was a precondition for a residence permit in Finland on the basis of Finnish origin, and that they only could take the exam once. What was exceptional in this data were the positive attitudes towards the language exam and studying the language: students reported that when the exam was coming closer, studying Finnish was more interesting and even more agreeable than it used to be. What learners think about the exam may have a strong influence on how they prepare for it and on how they succeed in it. This data shows that Ingrians had good chances to succeed in the exam.

Keywords: assessment; Finnish language; Ingrians; language exams; washback

\author{
Minna Martikainen \\ Jyväskylän yliopisto, Soveltavan kielentutkimuksen keskus \\ PL 35 \\ FI-40014 Jyväskylän yliopisto, Finland \\ minna.martikainen@tampere.fi
}

